\title{
Privatization Modalities and Business Valuation: An Ethiopian Focus
}

\author{
Fentaw Leykun \\ Department of Accounting and Finance, College of Business and Economics, Bahir-Dar University, Bahir-Dar, Ethiopia
}

Email address:

w.fentahun@gmail.com

\section{To cite this article:}

Fentaw Leykun. Privatization Modalities and Business Valuation: An Ethiopian Focus. Journal of Investment and Management. Vol. 9, No. 1, 2020, pp. 12-26. doi: 10.11648/j.jim.20200901.13

Received: January 8, 2020; Accepted: January 20, 2020; Published: February 4, 2020

\begin{abstract}
This paper has been ignited as a result of the current privatization movement by the Ethiopian government straight away as soon as the new prime minister comes into the position. The main motive of the government, behind the decision to privatize public enterprise to the local and foreign investor, was, inter alia, to limit government's participation in the manufacturing and service sectors of the economy so as to transfer the scarce resources from owned by inefficient public sector enterprises to efficient private entrepreneurs and to re-deploy such resources in higher prioritize and efficient private enterprises and to meet poverty reduction programs in a given economy, and thereby increase foreign exchange and alleviate the problem of good governance. In line with this agenda, various privatization modalities, theoretical debates, and arguments on such a privatization, and the various business valuation approaches have been critically reviewed via considering the current political and economic conditions of the country, and finally, contextual privatization strategies and business valuation methods have been implied at least to fairly redistribute wealth, institutionalize stock market and mitigate the common mistakes in the process of privatization of such public companies.
\end{abstract}

Keywords: Privatization Modalities, Privatization Strategies, Business Valuation, Mass Privatization, Conventional Privatization

\section{Introduction}

In the gradual process of privatization in Ethiopia, the agency known as "the Ethiopian privatization agency (EPA)), was established 24 years back in the year 1994 by proclamation No. 87/1994 and 146/1998. Since then, the process of privatizing public owned enterprises (POEs) has been delegated to EPA with the power and duties on investigating and making decisions on different claims of ownership with respect to the properties taken in violation of the important proclamations; Proclamation No. 110/1995 and its amendment proclamation No. 193/2000. The agency was established to be administered by the board of directors and to be managed by the general manager, and to be accountable to the ministry of trade and industry.

The EPA was established to accomplish the general objectives of generating sufficient revenue so as to finance development activities carried out by the government; to change the government's role and participation, and to divert its attention towards activities demanding more focus; to promote economic development via expanding and encouraging private sector's participation in the economy. Besides, EPA was responsible to perform the clearly defined tasks and duties as amended in accordance with Proclamation No. 146, issued in December 1998. This proclamation has got amendment in consecutive year of 1996, and later in 1998 by "Privatization of Public Enterprises Proclamation No. 146/98”, aiming privatization in bringing sustainable economic development via creating sufficient market and gradually reducing the government's involvement in the economy. Currently, EPA is merged with the then Ethiopian Public Enterprise Supervising Authority (PESA) to form the Ethiopian Privatization and Public Enterprise Supervising Authority (PPESA) in 2004 in accordance with Privatization and Public Enterprises Supervising Authority Establishment Proclamation No. $412 / 2004$. The PPESA is currently in charge of carrying out the public enterprises privatization process in ordinary and efficient manner. The (PPESA) is an autonomous government office entrusted with the tasks of privatization, 
supervision, guiding, supporting and controlling state-owned enterprises to render them competitive and profitable and thereby enabling them to play significant roles in the implementation of the country's industrial development strategy and the enhancement of economic growthi.

Recently, with the vision by the Federal Democratic Government of Ethiopia to make the country a middle income economy by 2025, the Ministry of Public Enterprises has been established by the proclamation no. $916 / 2015$, to provide for the definition of powers and duties of executive organs of the Federal Democratic Republic of Ethiopia (proclamation no. 916/2015). For that reason, the powers and duties which were given to the Privatization and Public Enterprises Supervising Agency by Proclamation No. $25 / 1992$ and with respect to public enterprises and shares to be privatized, and the powers and duties given to the Privatization Board by Proclamation No. 412/2004 are given to the Ministry of Public Enterprises. The justification behind this reform was that, in line with the developmental state policy of the country, the Ministry is believed to oversee and assists public enterprises who are accountable to other governmental bodies by studying their strengths and weaknesses and by sharing international experiences. Concerning enterprises accountable to the ministry, the Ministry has been give the responsibility to conducts the Privatization Program, and have the power to ensure whether enterprises have developed strategic and annual plan in line with policies, strategies and economic goals of the government, approve plans and monitors their implementation.

Privatization is a gradual process in the country Ethiopia; 166 state-owned enterprises were privatized from 1996 up to December 2000 [1], around 365 public enterprises have been privatized for the past two decades, since 1999, and both domestic and foreign investors have been participated in the investment, valued at 18 billion Ethiopian Birr (PPESA, News, 2015), 371 public enterprises have been privatized in the past two decades and have generated 24 Billion ETB (Simmons \& Simmons LLP, 2018). Recently, the Ministry of Public Enterprises (the Ministry) has tried to privatize around ten enterprises during the fiscal year 2016. Among others, Bahir Dar Textile S.C (via 1\% share sale), Combolcha Textile S.C (via 1\% share sale), Ethiopian crown Cork and Can manufacturing S.C (via $25 \%$ share sale), and National Tobacco enterprise S.C (via $60 \%$ share sale) were the four public enterprises already put for public tender. However, according to Simmons \& Simmons LLP 2018, out of these four companies the two Textile share companies have failed to attract bidders, and then after the ministry had passed decisions to privatize such less attractive enterprises via negotiation approach. However, the gradual privatization program in Ethiopia evolves the risk of pooling the public enterprises in the hand of few oligarchs (nazret.com, 2018).

In the light of the aforementioned ongoing activities of privatization, the federal democratic republic of Ethiopia executive committee has made its normal official meeting on 5/06/2018 in Addis Ababa, parliament hall. The committee has reported the economic advancement of the country for the past 15 year; the country has experienced the fast growing and sustainable economy; as if such an economy has motivated and initiated local and foreign investors, this created a chance to strengthen local and foreign investment in the country. The committee has also evaluated and identified further economic activities that need emphasis henceforth in the growth and transformation plan two (GTP II) and then. Besides, the committee has evaluated the activities performed for the past two and half year's achievement of the export trading in the growth and transformation plan (GTP2) of the country. The evaluation result indicates the lower performance of the export sector as compared to its targets. In alleviating such deficiencies, increasing product and productivity of the agriculture and manufacturing sector, with a special focus on export oriented products and services, are identified as economic activities that should be given special concern. According to the committee, the following areas have been identified as areas that need special attention: (a) to limit government's participation in the manufacturing and service sectors of the economy so as to transfer the scarce resources from owned by inefficient public sector enterprises to efficient private entrepreneurs and to re-deploy such resources in higher prioritize and efficient private enterprises and to meet poverty reduction programs in a given economy, (b) increase foreign exchange, (c) increasing the government's capacity in terms of generating more income from tax, (d) to simplify problems regarding the costs of living, (e) reducing unemployment, (f) bringing efficiency and competition in the economy, $(\mathrm{g})$ to control inflation $(\mathrm{h})$ alleviating the problem of good governance. In this regard, so as to fasten the existing economic growth with better export achievement that can be compared with the current economic growth, the government has justified and decided the need for economic reforms in the country. This reform is believed to bring, in the economy, the following benefits among others:

To mitigate the severe internal and external imbalance currently facing the country, to bring inclusive growth-Via allowing local investors to share in the country's mega projects so as to maintain sustainable economic growth in the country, to participate the Diaspora-via allowing those Ethiopians and Ethiopian citizens to play their own part in the process of developing their county's economy and to acquire technology and human skills-via foreign investors having better capital, technology and skills. In line with the abovementioned reasons, in general, the committee has passed the following decision: Those public owned manufacturing or service giving enterprises, currently on production or on establishment, such as rail way, sugar manufacturing, industry parks, hotel and other different manufacturing enterprises, fully or partially, should be privatized via share sales. In addition, the committee has decided to privatize, via share sales and with the government having majority of the shares, such relatively big and highly profitable public companies in the country; as Ethiopian air lines, Ethiopian telecom, Ethiopian electric power 
corporation and Ethiopian shipping and logistics enterprise. According to the federal democratic republic of Ethiopia executive committee, such big and highly profitable public companies are planned to be sold, via share sales, to both local and foreign investors. Regarding the practical execution of such decision, the committee has announced that its practical execution will be performed following the already existing developmental state policy by maintaining the fast and sustainable economic growth, and by keeping all other sustainable benefits to Ethiopia. Thus, for its practical excision, the committee has indicated as if the issue is to be detailed and supplemented with professional views with intense ethical manner.

Coming to the current situation of Ethiopia, privatization of the four big and highly profitable public companies; Ethiopian Air lines, Ethiopian telecom, Ethiopian electric power corporation and Ethiopian shipping and logistics enterprise, to local and foreign investors, and other public companies; rail way, sugar factories, Hotel industries and other manufacturing companies, solely to local investors, was declared with the justifications mentioned here above in the subsequent paragraphs.

In sum, this paper attempts to discuss various issues regarding privatization in Ethiopia. First, it tries to see the Characteristics of effective privatization strategies in general and in Ethiopia in particular. Second, reviews the Privatization Modalities experienced by the country. Thirdly,
Privatization trends and the level of attraction of enterprises of SOEs in Ethiopia have been critically reviewed. Finally, it tries to critically review the various business valuation approaches together with common errors in company valuations and justify the precondition to privatization, and reflected the ways forward for the current privatization practices in Ethiopia.

\section{Privatization Strategies: Characteristics of Effective Privatization Strategies}

An appropriate strategy must have three structural elements: a statement of objectives to be achieved, a program of action, and a commitment of resources to implement the action program [2]. Privatization strategies have been classified into two large families namely, Broad based ownership strategies such as voucher based programs and Conventional privatization strategies such as trade sale [3]. Government's approach to privatization varies across countries due to the four basic country specific characteristics; such as differences in government requirements with respect to the future operation of the SOEs by the acquirer, difference with respect to the nationality of the investor the government want to attract, type of related of unrelated diversification and the type of partial or fully owned acquisition [4].

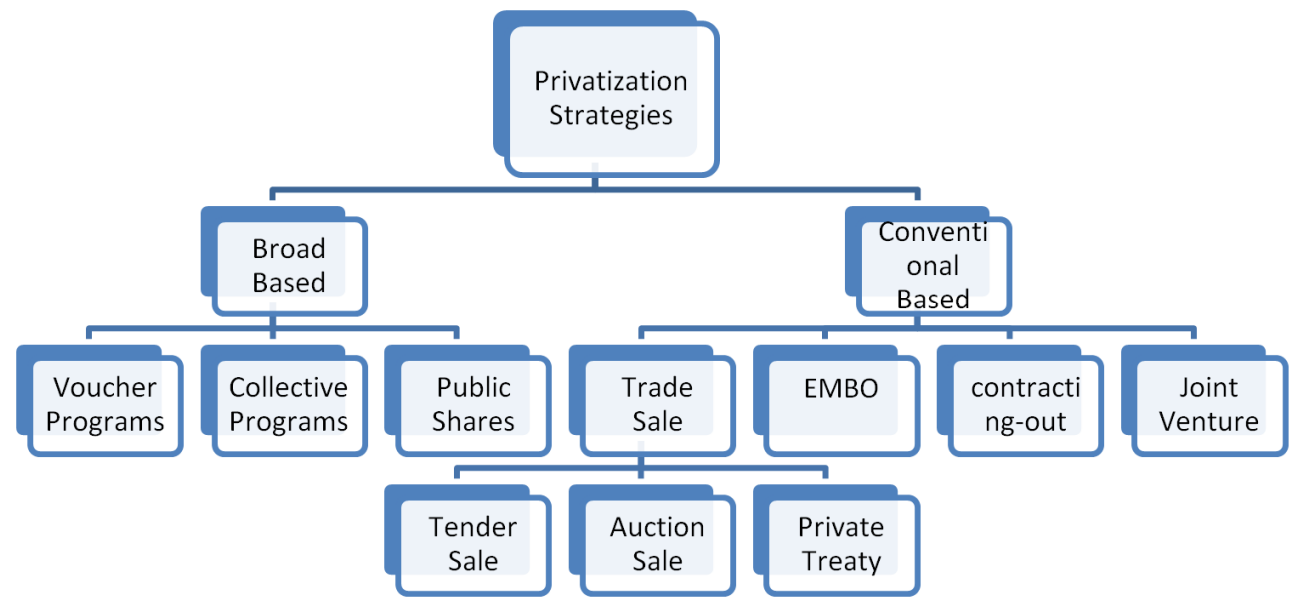

Figure 1. Privatization strategies.

Broad based or mass privatization, (voucher programs, collective programs and public shares), involves privatization of large number of SOEs in equitable ways which led to the development of three broad based ownership strategies; voucher based programs, collective investment programs and public share offerings. These strategies are preferable due to the reason that they are politically popular, have better redistributive results, and can help capital market development [5]. This strategy can play an indispensable role on three major issues; political, wealth redistribution and institutional. Politically, it can make possible the spreading share ownership to the people at large or to specific subgroups such as the poor or an ethnic minority and some oligarchies. Besides, government can use this strategy to address the concern of wealthy distribution among the citizens, and at last the government can use this strategy in developing and deepening capital markets and related institutions as well [6]. On the other wing, the conventional/traditional strategies, (trade sale, EmployeeManagement buyouts, contracting-out and joint venture shares), have been playing their own role in privatizing SOEs in a given economy conventionally. The conditions where each of the broad-based and traditional privatization strategies may be preferable are discussed here in the next consecutive paragraphs.

Literature suggests that vouchers have been widely used in 
transition economies of Eastern Europe and the former USSR [7]. This strategy involves the distribution of coupons or certificates to participants which could later be converted in to shares via financial intermediaries, in most cases vouchers can also be freely traded for cash. Vouchers work best in a situation where its distribution and trading centers are easily accessible and where there is a competent administrative system for their distribution and registration. As far as collective investment programs, (that include investment trusts and privatization trust funds endowed with government-owned equity, pension schemes funded from the earnings of SOE shares, and non-voucher-based unit trusts), as a strategy of privatization is concerned, these collective strategies have feature different from the broad-based strategies; it does not necessarily involve distribution of paper vouchers and as a result of which this method is found simpler to administer and usually require lesser resources to take-off; there exists a restricted entry and exit to participants, individual citizens do not own shares in trust funds rather the assets are collectively owned and held for the benefit of the present and future citizens, and as a result, there is no direct and immediate financial gain for participants. These collective strategies programs are usually preferable for Policy makers in a situation where; there are weak and constrained capital markets, there is little understanding of share ownership, there are cultural barriers to individual accumulation of wealth, there is a low level of literacy, and there are logistical problems such as a highly dispersed population that is difficult to reach [5]. Public Share Offering, as the third elements of the broad-based strategy, is used in a situation when huge amount of capital needed to be raised having widespread ownership as a major objectives of a privatization accomplishments. This approach has the ability to create great public awareness though it is technically difficult; it demands great care in the process of selecting SOEs among hundreds or thousands and demands detail careful planning for the floatation. The government can invite applications for the share at a set price via public offerings. In this approach, the government as well as underwriters can determine a rate or ration to allocate to allocate the shares where the issue is oversubscribed. However, to be successful, a public offer requires a welldeveloped financial market and an efficient system of corporate valuation $[6,8,9,10]$.

In sum, the broad-based methods, especially the voucher programs, are usually criticized from the point of view of the creation of dominant owner that will induce good management of privatized SOEs due to the much diffused nature of ownership, and hence reservation of majority of the shares for a core investor and distributing the reminder for others is recommended as the best way out of that problem, and if one fail to do so, the political and social gains could be scored at the expense of very high economic benefits [5].

Concerning the traditional/conventional privatization strategies; trade sale can be accomplished by tender sale, auction sale and Private Treaty. Regarding sales by tender offer such activities are expected; the government solicits bids from private investors for a predetermined percentage of stock above the minimum tender price, bidders are expected to prepare a management proposal that basically states the magnitude of many they want to invest together with their intention to have such stocks in such enterprises for a specified time span, then these bids latter be reviewed by the government and be selected on the basis of investor's financial strength, reputation, experience, and quality of investor's management combined with investment plan. This method has its own advantages and disadvantages: as an advantage, the method leads to accurate pricing since the price is set by demand and supply and it is found difficult for investors to get collude/conceal, it, from the very beginning, produces market valuation of the enterprise and thereby facilitating subsequent trading, randomness / unpredictability / uncertainty, delays, corruption, and unnecessary cost can be reduced in this method. Besides, the successful bidder will be the highest value user with the potential to realize the largest efficiency gains, it gives investors a opportunity to buy what they want to buy (they can choose what shares to buy with less susceptible to manipulation), it can boost up corporate governance while winners are among institutional or strategic investors with a majority stake in the enterprise. On the other hand, there are major problems related to this method; in a situation where there is imperfect capital market efficient resource allocation may not be ensured, that is minimum efficiency can be maintained via participating large number of bidders, if potential investors/bidders cannot participate or fail to afford the required money, this method will result in low prices, and the privatized SOE will end up in the hands of the lowest value users, it works against small investors having difficulties in raising sufficient amount of capital even if they could manage SOEs in more efficient ways than the large investors [6]. This is particularly true in African context, in which Ethiopia belongs, where the capital markets are either non-existent or very poor.

Auction sale, as one of trade sale methods under the conventional privatization strategy, it has the very feature of buying competition that is concentrated in time, no need of restatement or indication of prices, rather the price will go up ward until one bidder remains and that last price will be taken as sales price/lowest competitive price at which demand equals supply. This method allows the seller to become a monopolist as far as theory of optimal auction is concerned (i.e. assigns all bargaining power to the seller, subject to the constraint that she does not have access to buyer's private information about the asset's value at the sale), in that the seller can set a minimum price/reserve to maximize the expected profits [11]. Besides, this method if found expensive in relation to widespread advertising and is vulnerable to market condition changes since the process takes much time that, conventionally, ranges from six to eight days. It is not found to sale every type of property, rather it is suitable for sales by order of trustees, executors, mortgagees or liquidators, and for properties with considerable expected competition or when there is a prescribed time for the owner to sell the property or when the assessment of the value of the 
property is difficult. Furthermore, the political sustainability of the outcome; the robustness of firm's bidding strategies; and the opportunities for collusion among firms, makes the choice of this method arguable, and all these together determines whether an auction design yields value; how that value is distributed among bidders, consumers, and the government; and whether the deal will last [12].

Sale by Private Treaty, among other conventional methods, is accomplished in such a way that the government chooses the buyer and negotiates an agreement with the single buyer; here negotiated sales are used only when one buyer is selected by the government in its views as compared to others. As an advantage, this method is found relatively cheaper with no instant time stress, private negotiation with bargaining power opportunities. However, it do have such things as disadvantage; it advertises prices (assumed to be the top price negotiation, price will get downward), uncertainty about conclusion of sale until contracts are exchanged and less transparent than open bidding and hence more vulnerable to abuse [10-11].

Under Management-Employee Buy-Outs (MEBO) method, a holding company is to be created in which managers and employees buy controlling interest from SOEs, the holding company is then forming its capital structure from debt and equity and latter pays interest on debt and its principal from dividends earned latter in the privatized company. This method is found very risky that could be explained in terms of lack of entrepreneurial experience from the side of the work force, probability of operating and financial problems; it may inhibit or eliminate competition in the privatization process due to its emphasis on insiders. On the other hand, this method does have advantages also that could be explained in terms of minimizing social cost associated with layoffs and liquidation of enterprises, enhancing future productivity due to sense of belongingness of the work force $[6,8]$.

In views of the conventional methods, contracting-out is a traditional/conventional method where the private operator contracts with a government entity to provide capital intensive service such as water and electricity supply, garbage collection, and other public works in accordance with certain performance standards, and in turn the government guarantees the market and maintain control via using service fee payment as incentives for performance. The method is also known as decontrol, i.e., continued state ownership but requiring the enterprises to be on the basis of efficiency criteria, would mean privatization of management through leases or management contracts. This may be preferable alternative in cases where private investors cannot or will not buy SOEs. It is argued that, on the one hand, managers will have vested interest to make the enterprise succeed, and, on the other hand, hired managers will not have the same degree of motivation as owners [13]. Besides, management contracts, and operating leases \& concessions are considered as other modified versions of contracting-out. Various advantages are associated with this method; it generates savings due to competition that leads to reduced service cost and improved service quality competition, the program can be adjusted in line with the rise of service demand without having employee layoffs, as a result, makes the entire cost of the project viable, promote better management and objectivity, provides powerful incentive and new projects can be started without large initial capital outlays [6]. On the other hand, this method is susceptible to abuse due to the monopoly in hand; the desire to obtain contracts can encourage bribery, kickbacks, and payoffs, the profit motive may lead to cost-cutting practices that could lead to service quality reduction, competition may be impaired in particular areas where the initial entry costs are high, thus renewal of contract being automatically granted to the existing operating company.

Joint Venture shares, as a hybrid method, which reflects the features of trade sales, public share offering and management contracts, has been viewed as the most immediate method of method of attracting foreign direct investment (FDI). Through this method, such needs of a country as foreign capital, technology transfer, operational know-how, and the building-up of infrastructure, can be merged with investor's need in business expansion and profitability. Such a joint venture Agreement takes various legal forms ranging from simple trade agreements to jointly owned companies. In this regard, some governments contractually restricting via pre-emptive rights the rights to transfer ownership of a company's securities with private investors, may lead governments to uncomfortable situation that may challenge and undermine further privatization at any good price in future [14].

Any country success on privatization depends on the match of strategy, organizational capabilities and timing...no one policy can succeed for every country and certainly not for all at the same time [15]. Privatization is neither a simple nor a uniform process, Starting points differ; countries have varying objectives, face a wide and shifting range of problems and obstacles, and thus need to adopt different strategies and tactics to achieve their privatization objectives. There is no universally applicable approach to privatization, and the attempt to apply a "one size fits all" approach has proven ineffective and counterproductive. Nonetheless, worldwide experience does provide some guidance on the factors critical to the success of privatization [16]. The role of Authority vs. Markets in government industrial policy particularly important in the context of privatization due to the fact that purchase of an SOE is different from the other acquisitions in that the government can change/alter the market conditions and deals before, during and after the acquisition, leaving an acquirer particularly vulnerable (i.e. when public policy replaces markets, transactions become subject to public policy contingencies-politics can cause public policies and their targets to change without notice) [15]. To that regard, various success factors have been identified in the literature; strong political commitment, Ownership and competition, Transparency and Mitigating the social impact of privatization (see [16]. The success of privatization will depend on collaboration between government and firms, which in turn 
depends on credible government commitments [15]. In addition, historical differences, political and social differences, and the presence or lack of financial markets are likely to alter three things: the government's approach to privatization, the degree to which SOEs will become market controlled and the degree to which governments will try to control privatization process and the characteristics of the firm after privatization. In addition, individualism vs. Communitarianism, economic vs. Political objective in decision making, and equity concerns vs. Efficiency as a base for decision making will likely also affect the characteristics of privatization process [4]. However, in views of the key success factors for privatization, privatization has impact on five basic aspects as identified in the literature: inter alia, it does have impact on Enterprise performance, Macroeconomic and fiscal effects, Welfare consequences, Employment effects and Wealth and income distribution [1617].

In views of the various characteristics of privatization as mentioned so far, an effective privatization strategy must have the following characteristics [2]: have mutually consistent goals and policies which are clear and transparent to all; respond to the country's environment and be compatible with it, indicating relationships with other ongoing policy initiatives; be feasible within the resource capabilities of the country; create more opportunities for the country and avail greater competitive advantage; it should be comprehensive in all aspects and it must have a mechanism for implementation.

\section{Privatization Modalities: Ethiopian Focus}

Privatization has imperative socio-economic implications for the various interest groups in a country. Privatization and public sector reforms have been more demanding both politically and in terms of administrative resources, than other measures such as exchange rate and price reforms, which brought about macroeconomic stability, it is a politically charged subject is in sub-Saharan Africa, as many other developing countries. Besides, recently, donors and multilateral agencies have made privatization a key conditionality, and as a result of which more African countries are indeed undertook privatization in order to moderate donor fears over domestic reform commitment, that is out of ideological or economic certainty. Thus, privatization touches a complex set of issues, including property rights, nationality, ethnicity, bureaucratic practices, donor conditionality, nature of markets and politics [19].

According to this author, subjective evidence suggests the existence of wide variations in African countries in terms of the ways that privatization strategies and plans have been introduced, debated and executed; some countries rapidly overcome the opposition towards privatization from influential groups such as labour unions and consumer groups; while some governments quickly overcome opposition to privatization from influential groups, such as labour unions and consumer groups, and were able to transfer a lot of state owned enterprises, others failed to go much beyond the initial divesture of small companies or re-privatization (the return of shares acquired during earlier nationalizations). Arguably, it is not always the capitalist-oriented African countries that promote privatization speedily (e.g. Kenya and the Côte d'Ivoire), but also the formerly socialist-oriented, (e.g. Mozambique and Tanzania), have been faster in implementing privatization. In the process of privatizing public enterprises, such issues as liquidation, denationalization/reprivatisation, decontrol and privatization are found essential options or may be steps to deal with the matter [13].

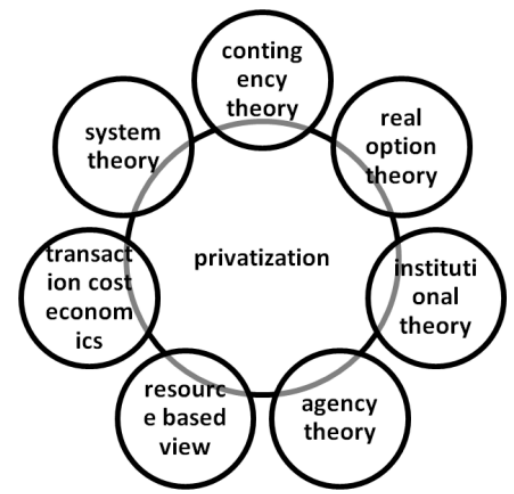

Figure 2. Alternative theoretical frameworks for privatization as adapted from Carter, (2013).

Even after privatization, debate often continues around such issues as the divestiture sequence, size of the firms to be sold and the speed at which privatization is to be undertaken, as well as the method to be used [19]. The divestiture of small firms in many African countries, almost exclusively sold to 'nationals' or simply liquidated, even companies were end up in the hands of bureaucrats and politicians, elicits little controversy on the matter. However, large controversy elicits from the privatization of large companies, particularly those thought to be 'strategic'. The latter is the worry of Ethiopian government following its decision to privatize some big public enterprises, such as Ethiopian airlines, Ethiopian telecom, Ethiopian electric power corporation and Ethiopian shipping and logistics enterprise. Some of the controversies are; first, the comparison between domestic and foreign ownership, since these companies are too big to afford for domestic capitalists; second, the risk of consolidating the state owned enterprises in the hand of few oligarchs due to the current political instability in the county; thirdly, the idea of 'sunk costs' is not well concerned by the politicians and general population. They assumed of such large state-owned enterprises to be worth at least a good fraction of the millions spent on their rehabilitation or on loans to them by the government, regardless of the concept of efficiencies. Rather, the sale of national treasures at distress prices causes and will cause much political dissatisfaction in the country. In deference of such controversies, many African countries have experienced privatization; for example, Uganda is an exemplary of fast privatization, since 1990s, of such companies as the government-owned newspaper the 
new vision, the national airline (with de facto liquidation) and the Uganda Electricity Board, among others.

In line with the aforementioned controversies, [19], have identified four models/phases of privatization based on speed of privatization and volume of sales as shown in the figure bellow: Stalemate, Path of least resistance, Breaking resistance and Fully-fledged.

The position of minimum movement, slow privatization process and small volume of sales is referred to as Stalemate. In other words, it is a situation in which no progress can be made or no advancement of privatization is possible, and it was the case for many African countries in the late 1980s. The social conflict and political crises were among the factors constrained countries not to move further in the privatization agenda. Another scenario which was quite common in subSaharan Africa is the "path of least resistance "which is characterized by the rapid privatization of small firms during 1990s, among African countries; Zambia was too active by privatizing around 200 companies during the first five years of privatization of the year 1990. It was one of the fastest and transparent privatization in Africa [19]. Finally, the stock of such small firms has got exhausted and the government has tend to privatize larger ones, it was at this time that the privatization dynamics was virtually created and the moment was partly taken as a process of learning from prior mistakes, introduce new legal codes strengthening the administrative and financial aspects of the process, including the introduction of new legal codes to remove loopholes.

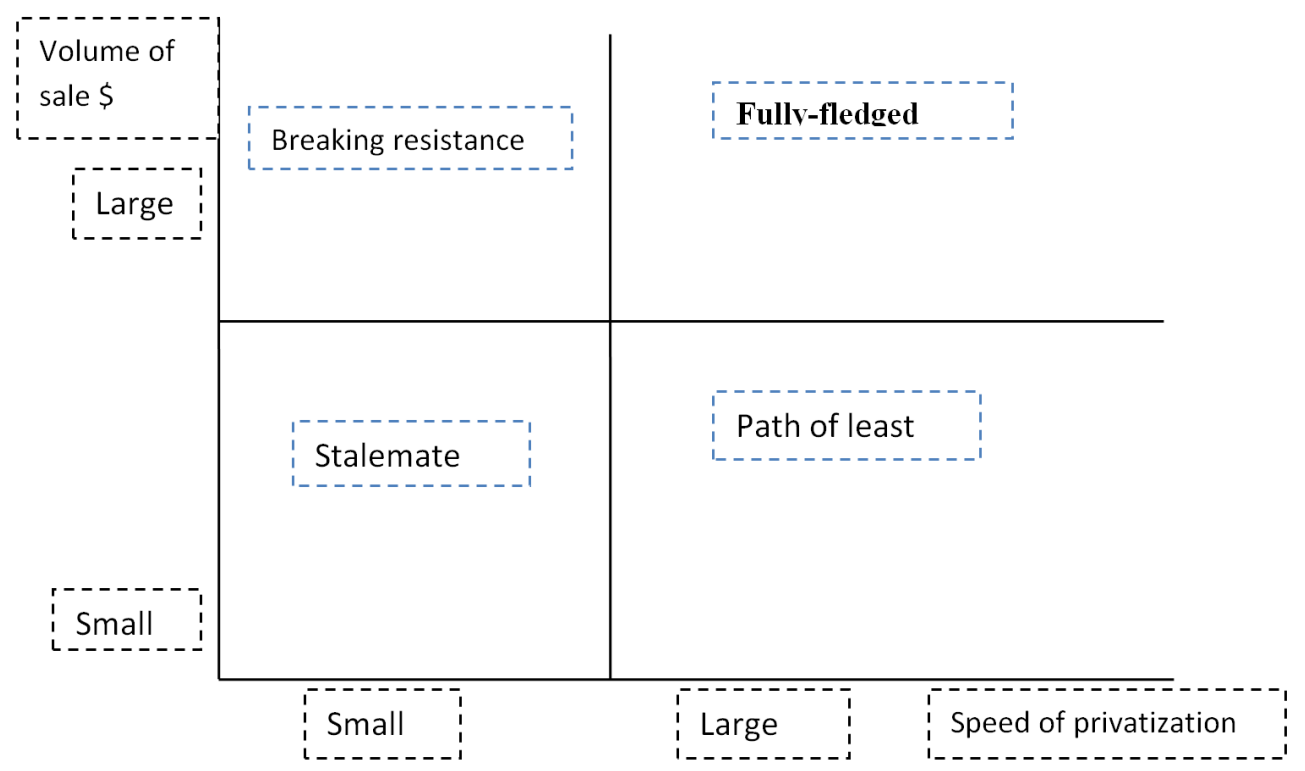

Figure 3. Phases of privatization: Source: Steve, (2002).

Moreover, most of sub-Saharan countries were characterized by the third phase 'breaking resistance' during the first half of the 1990s. It was at this phase, in the privatization process, that the issue of privatization has been accepted in principle, legislative and institutional frame works was under way. However, large firms were suffering from institutional and political constraints since large firms were taken as symbols of national independence, made privatization much slower than before. Although, the sabotage of political the agenda against the divestiture of big companies, some governments were able to privatize one or two of their big enterprises in 1990s, Kenya and Côte d'Ivoire were the one among others privatized Airways and the electricity conglomerate via the issuance of a 10 years lease contract to a French company, respectively. The Fullyfledged, as the four phases of the privatization process, only practiced by few African countries, was realize after the political and institutional constraints got resolved. This phase is characterized by the privatization of big companies that were considered as strategic (as symbol of national independence) in various sectors such as telecommunication, electricity, water and other utilities. The practice involves divestiture including the sales to the foreigners with no or little controversies. This phase differs from the "Big Bang" privatization strategy that was commonly practiced in the transition economies of Eastern Europe, most noticeably voucher privatization ${ }^{1}$ schemes in Russia, the Czech Republic and to a lesser extent by Poland. The concept of "Big Bang" is that of mass privatization of state enterprises as quickly as possible, with the rationale as justified by [20]: Privatization then offers an enormous political benefit for the creation of institutions supporting private property because it creates the very private owners who then begin lobbying the government...to create market-supporting institutions... [Such] institutions would follow private property rather than the other way around.

According to [19], the rationale there was that every citizen had to be given an equal share of the former property of the state for reasons of fairness. For this strategy to succeed, however, central bureaucracies were suffering from credibility problems in Europe so as to defend themselves against the

1 Voucher privatization is a privatization method where citizens are given or can inexpensively buy a book of vouchers that represent potential shares in any stateowned company. 
serious attack on their incomes and rents implied by the rapid reduction of the public sector. Moreover, the Russian voucher privatization program has failed to realize fundamental objectives that could facilitate economic development, in spite of achieving impressive results when measured by the number of enterprise privatized. Undesirable features of voucher privatization have made other privatization methods more attractive to the personnel of most enterprises. Voucher privatization does little to affect needed enterprise restructuring, and it has not achieved even modest equity goals. The privatization program was dominated by the political agenda, created difficulties that predictably undermined political legitimacy among the Yeltsin (president of Russia, 1991-1999) reformers. A significant failing of the program has been to divest the state of property without first having developed measures to promote the survival of newly privatized enterprises in an alien economic environment [14, 21]. Even, under fully fledged privatization, voucher privatization has not been attempted in sub-Saharan Africa, though; governments have got more experience and strengthen legal frameworks under this phase of privatization.

There are various privatization options or modalities which are arguable based on a country's economic, political will and stability, the level of state effectiveness, among others, to be prioritized and practiced. These are; liquidation, reprivatisation (denationalization), decontrol and privatization. Liquidation, ahead of the rest, is found par amount important in a situation where the enterprise is sick and has no prospects at all of operating profitably. However, unemployment is one among the major problems in this case. In views of the privatization modalities, denationalization/reprivatisation involves the returning of nationalized enterprises to their former owners, but it has nothing to do for to address the problem of those that are always be state owned or originally state owned enterprises. It is susceptible to problem of employee layoffs and inefficient private monopolies. Decontrol, involves the continuation of state ownership and it demands enterprises to be operating on the basis of efficiency criteria, which is to mean privatization of management through leases or management contracts. This may be preferable alternative in cases where private investors cannot or will not buy SOEs. It is argued that, on the one hand, managers will have vested interest to make the enterprise succeed, and, on the other hand, hired managers will not have the same degree of motivation as owners [13]. The other alternative is privatization; partial (in which case only a given percentage of assets will be transferred to private investor, arrangements for joint venture may be created from both local and foreign investors) or full (in which case all assets will be transferred to private investors). Privatization has its own privatization modalities; selling to private entrepreneur (involves the risk of private monopoly, inefficiency and no gain to the general public), selling to the general public by floating shares (the critical problem here is whether the public at large have the capacity to buy shares, unless it is accompanied by a massive lending program it is unlikely to be viable), selling to the employees of the enterprise with a question that whether they have the capacity to buy. What so ever it is, in choosing among the alternative modalities, the objective of privatization should be to increase the competitiveness of enterprises and reduce the financial drain imposed on government, and take in to account that private enterprise is not everywhere synonymous with efficiency [13].

Table 1. Interest groups, threats and benefits in the privatization process in Ethiopia.

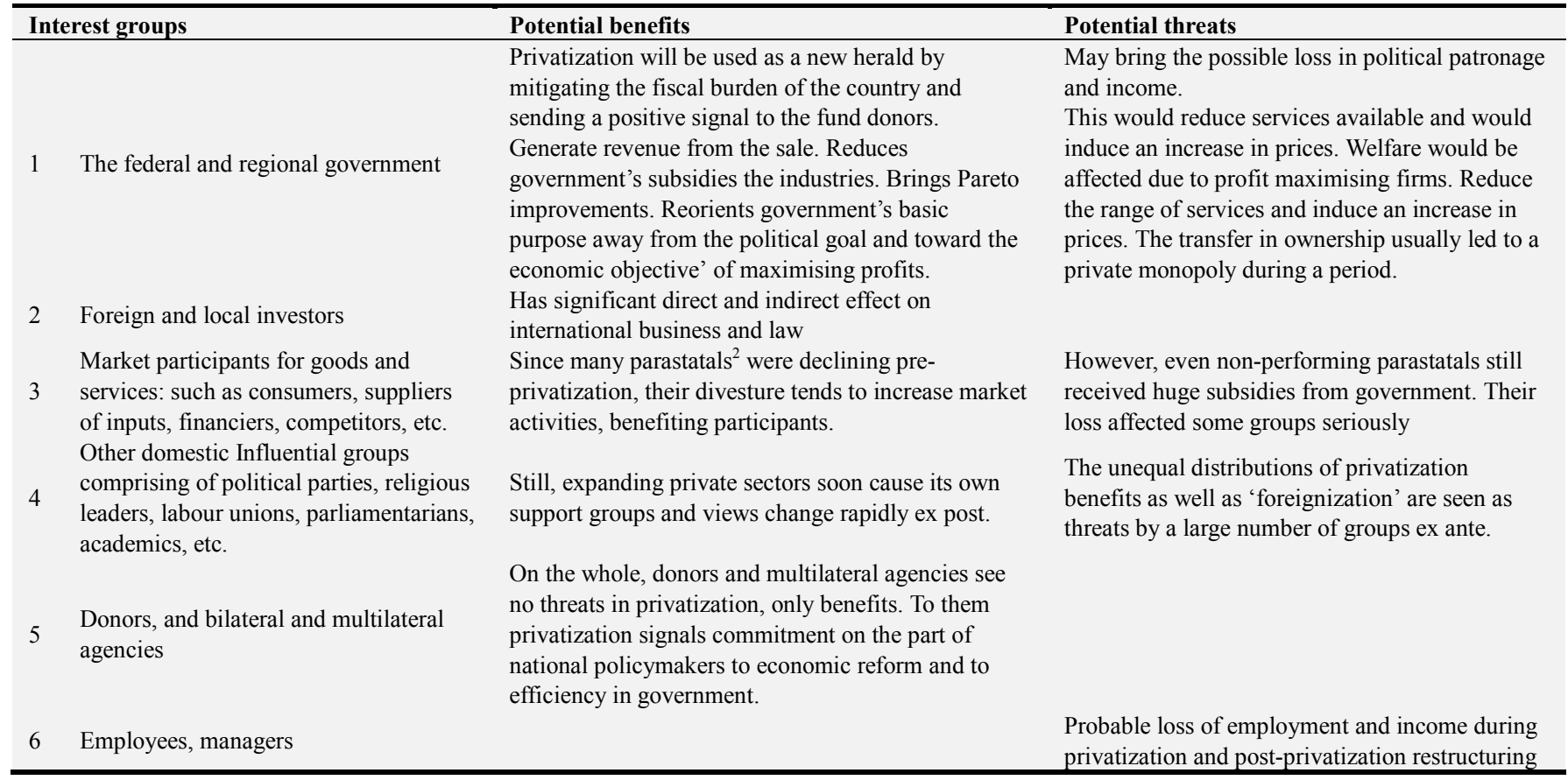

2 An organization or industry, especially in some African countries, having some political authority and serving the state indirectly 
Table 2. Arguments for privatization.

\begin{tabular}{|c|c|c|}
\hline Bases & Privatization & Nationalization \\
\hline Ownership & Enterprise owned by private sector & Owned and managed by government \\
\hline Incentives & Profit motive acts as incentive for owners and managers & Workers may feel motivated if they feel company belongs to them \\
\hline Externalities & $\begin{array}{l}\text { Private firm may ignore external costs and benefits (i.e. } \\
\text { from corporate social responsibility) }\end{array}$ & Government can put social benefits above profit motive \\
\hline Efficiency & $\begin{array}{l}\text { Incentive to introduce new technology and increase } \\
\text { labour productivity }\end{array}$ & Nationalized firms may find it hard to sack surplus workers \\
\hline Knowledge & Private firms employ managers with best skill & Politicians may interfere based on political motives \\
\hline Natural monopolies & $\begin{array}{l}\text { Private monopolies may charge high prices, e.g. water, } \\
\text { train, etc }\end{array}$ & Government can set price based on social factors \\
\hline Depends on industry & Worked well for some & $\begin{array}{l}\text { Natural monopolies like, train/ water. None profit service like health } \\
\text { care. }\end{array}$ \\
\hline
\end{tabular}

\section{Privatization Trends: Stylized Facts from Ethiopia}

To talk about privatization trends worldwide since the late 1970s, the year 2008 can be seen as a point of demarcation for the sources of disaggregate and aggregate data. The World Bank has been the sources of data on privatization prior to 2008 (with a regional breakdown) but unfortunately this was discontinued in 2008 and no consolidated data is available after that date. After the year 2008, it is found impossible to find out disaggregated data, and researchers therefore have been presenting world aggregates, based on the Privatization Barometer database [22-23].

The focus of the earliest literature on privatization was on developed economies and Western Europe represented around one-third of the world's privatization proceeds in the period 1977 to 2002 [24]. According to [22-23], there were also impressive numbers of privatizations after 1990, during the transition process, in Central and Eastern Europe, with revenues estimated $\$ 240$ billion to 2008, in addition to widespread free or subsidized allocation of shares in former SOEs. However, proceeds from privatization have been more limited in Africa, the Middle East and South Asia, with total proceeds below $\$ 50$ billion for each (Estrin \& Pelletier, 2018). Different results have been registered for the rest of Asia. South Asia, especially India, has experienced limited privatization, where as in east Asia high amount of privatization has been occurred, with the proceeds represented $30 \%$ of the world's total ( $\$ 230$ billion) over the 1988 to 2008 period.

Among Asian countries, china was outstanding over a 25years period, the government of china was characterized in terms of encouraging innovative forms of industrial ownership, focusing on sub-national level, that combine elements of private and collective property, new private entry and foreign direct investment (FDI). As a result, by the end of 1990 s, $60 \%$ of the total GDP has been contributed by the non-state owned sectors; consequently the share of SOEs industries has declined from $78 \%$ in 1978 to $28 \%$ in 1999 (Kikeri \& Nellis, 2004). As per the estimation by OECD the share of SOEs as a percentage of GDP is further declined $29.7 \%$ by the year 2006 . Large scale privatization programs have finally been launched in Latin America, especially in Chile, especially in the infrastructure sector, starting in 1974 in Chile and reached at peak in the 1990s. Between 1988 and 2008, the total privatization proceeds in Latin America amounted to $\$ 220$ billion (28\% of total world proceeds). In general, in those periods, the share of privatized firms from the total GDP $(0.5 \%)$ was high in Latin America.

Concerning privatization since 2008, privatization was marked by the predominant roll of china five years to 2015 in the globe with total proceeds of $\$ 40$ billion in both 2013 and 2014 and a spectacular $\$ 133.3$ billion in the first eight months of 2015 through 247 sales. The United Kingdom was the second leading country in the privatization with total proceeds of $\$ 17.2$ billion in 2014 (against $\$ 7.8$ billion in 2009). While the privatization programs in Eastern Europe, China, and Latin America are among the most important in terms of total proceeds. Moreover, while privatization in Latin America and Eastern Europe culminated in the 1990s, much privatization in Africa and South Asia is more recent [25] cited in [23].

During the transition process in Central and Eastern Europe, remarkable privatizations have been taken place with a total proceed of US\$240bns over the period 1988-2008. During this time period, this picture is somehow contrasted in Asia, a limited privatization experience has been shown in south Asia, particularly in India, as compare to East Asia with total privatization proceeds of US $\$ 230 \mathrm{bns}(30 \%$ of total world proceeds) over the period of 20-year, from 19882008). Eventually, large-scale privatization programs have been launched in Latin America and especially in Chile with especial focus in the infrastructure sector, from 1974 in Chile to 1990s. All through the period 1988-2008 the total privatization proceeds amounted to US\$220bns in Latin America (28\% of total world proceeds).

In views of privatization programs in sub-Saharan Africa countries, it has occurred in successive waves, with some countries privatizing much earlier than others [26]. Countries participated in the program have been grouped in to three. Francophone West African countries such as Benin, Guinea, Niger, Senegal and Togo were the first group to start privatization programs in the late 1970 s to early 1980 s though their progress in the program has been limited. Anglophone and Francophone countries, such as Ghana, Nigeria, Ivory Coast, Mali, Kenya, Malawi, Mozambique, Madagascar and Uganda, were the second group of countries to get on in the program in the late 1980 s as a result of 
pressure from the international financial institutions [27]. The third/last group of countries which lately embark on privatization program known as "late starters" didn't start the program until the early-mid 1990s. Countries in this group, among others, are Tanzania, Burkina Faso and Zambia have shown a strong political commitment to privatization, whereas in the other three countries (Cameroon, Ethiopia and Sierra Leone), only minimal progress had been made by late 1995 [28].

\section{The Level of Attraction of Enterprises}

Ejigu, assistant professor, accounting and finance department, Bahir Dar University, has forwarded his views on the motive for privatization of the said public enterprises in Ethiopia: The main motive behind privatization is acute shortage of foreign exchange. Even the plan commission head Dr Yinager was justifying most of these firms will be availed for sale for foreign investors, not for local ones, Dollar crisis is at the heart of the fire sale. Because they are in dire need of dollar, even the foreign buyers can bargain and buy at discount. The country is close to an economic collapse, 1.4 trillion ETB debt burdens, out of which 26 billion Dollars are borrowed from foreign lenders and the rest of the entire figure from local lenders such as banks. The many years looting, false economic growth number is making the demise sooner than later. The economic crisis will unfold faster than the political crisis. "I am against privatization in the current form. The argument goes on like this. I believe that the main motive of privatization is shortage of dollar. The government borrows dollar in the past for many projects. All those projects are wasted and corrupted. They can't generate the needed revenue to pay off their debt because of corruption. Thus those who corrupt those projects should return the dollar they smuggle and the debt should be paid off like that. It is too foolish to privatize to pay off your debt which is corrupted by those blood suckers. So unless the blood suckers are held accountable, Dr. Abiy, the prime minster of Ethiopia, can't sell anything. If He sells know that you are acting against public interest".

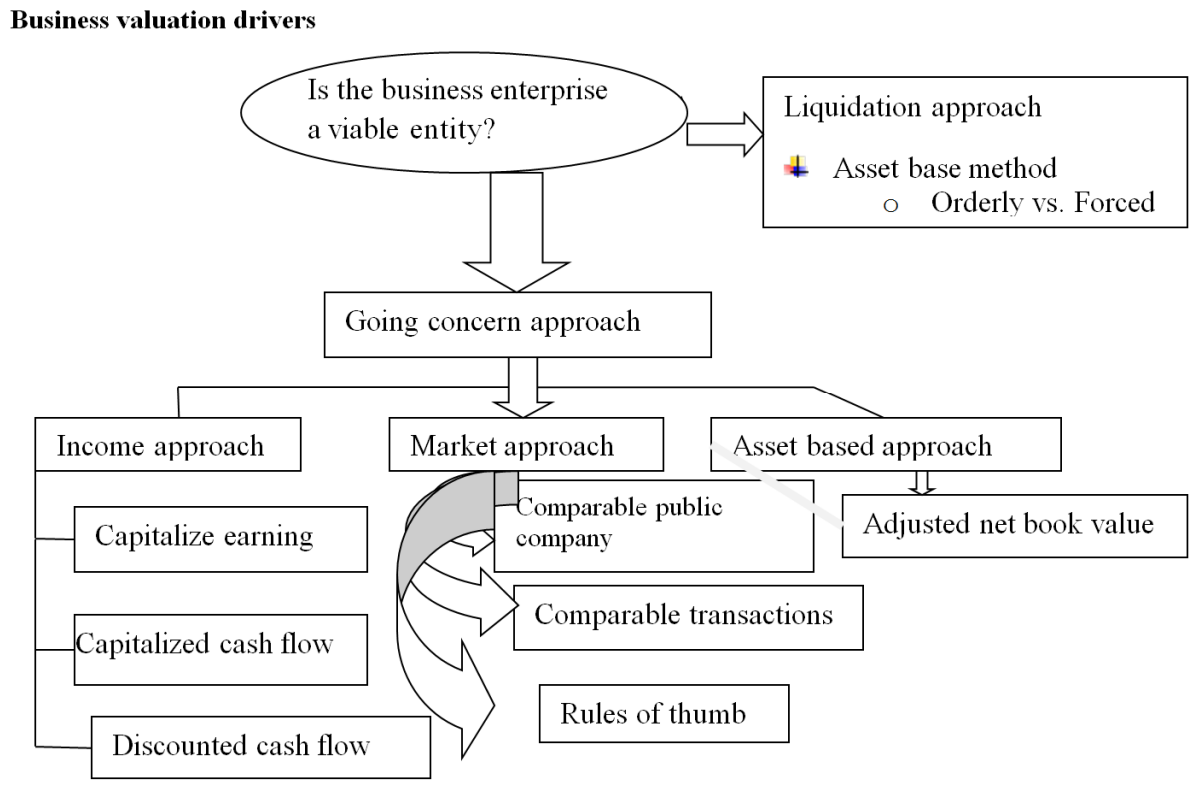

Figure 4. Valuation approaches and methods-going concern approaches.

\section{Business Valuation Approaches and Process}

Valuation is the process of determining the "economic worth" of an asset or company under certain assumptions and limiting conditions and subject to the data available at the valuation date (International Valuation Standard Council). Business valuation is the process of determining the economic value of a business or company (investopedia). According to Business Valuation Tools for Mac \& Windows, business valuation is a process that involves a set of procedures used to determine what a business is worth. The practice of business valuation is not as simple as its definition; valuation requires sound preparation and thought. There is no one way of business valuation: valuation result varies depending on the assumptions considered; business valuation means different thing for different people, for example a business owner may believe that the contribution of the business to the community it serves is worth a lot than the income generated from it. On the other hand, an investor may think and define the business entirely by its historic income. In addition, the value of a business can be affected by economic conditions and the circumstances of a business sale. For example, when there is unemployment/job scarce in the economy, more business buyers enter the market and increased competition results in higher business selling prices. There is a big difference between a business values valued in different circumstances; a well-planned marketing effort to attract many interested buyers and a quick sale of business assets at an auction. In sum, the factors affecting business value have been framed by [29], as risk factors 
(external risk, internal risk, and investment risk) or systematic-uncontrollable by an organization and macro in nature (e.g. interest rate risk, market risk, purchasing power/inflationary risk) and unsystematic risk-controllable by an organization and micro in nature (business risk/liquidity risk, financial risk/credit risk, operational risk); competition; investment alternatives; economic environment; history of business; nature of business and financial performance.

A conceptual framework for business valuation drivers has been justified by [29], as published by South Africa institute of professional accountants. The conceptual framework comprises of six drivers of business valuation; financial leverage, future performance, financial expected return, cash flows, asset types and exit strategy as shown below. Business Valuation Tools for Mac \& Window has justified the three approaches to determine how much a business is worth: income approach/earning value approach, asset-Based approach and market value approach.

\subsection{Generally Accepted Business Valuation Approaches and Methods}

\subsubsection{Earning Value Approach/Cash Flow Methods}

It is found perfect to explore the intrinsic value of any business by evaluating the cash flows, net present value, equity method, and economic profit model. The common methods involving business evaluation in this approach are capitalized earnings, capitalized dividends and discounted cash flows. The capitalization method of business valuation under income/earnings value approach involves the determination of capitalization rate (discount rate-growth rate) i.e. discount rate calculated as weighted average cost of capital and growth rate should be in between (1-5\%). consequently, enterprise value could be determined as average earnings scaled by the capitalization rate. Besides, in the process of estimating earnings, there are various factors that need to be considered; business model, market position, competitive advantages, product position, cost structure, the strength of management, operating strength/weakness, location and accessibility, customer base, barriers to entry an supply chain, inter alia. The capitalized dividends method involves the distribution of profits in cash or equivalents-cash flow to shareholders. The specific methods that can be used in dividend valuation are; dividend capitalization (capitalize future dividend at expected return), discounted cash flows (present value of future dividends discounted at expected return) and Gordon growth model (capitalize the future dividends at the expected return inclusive of growth).

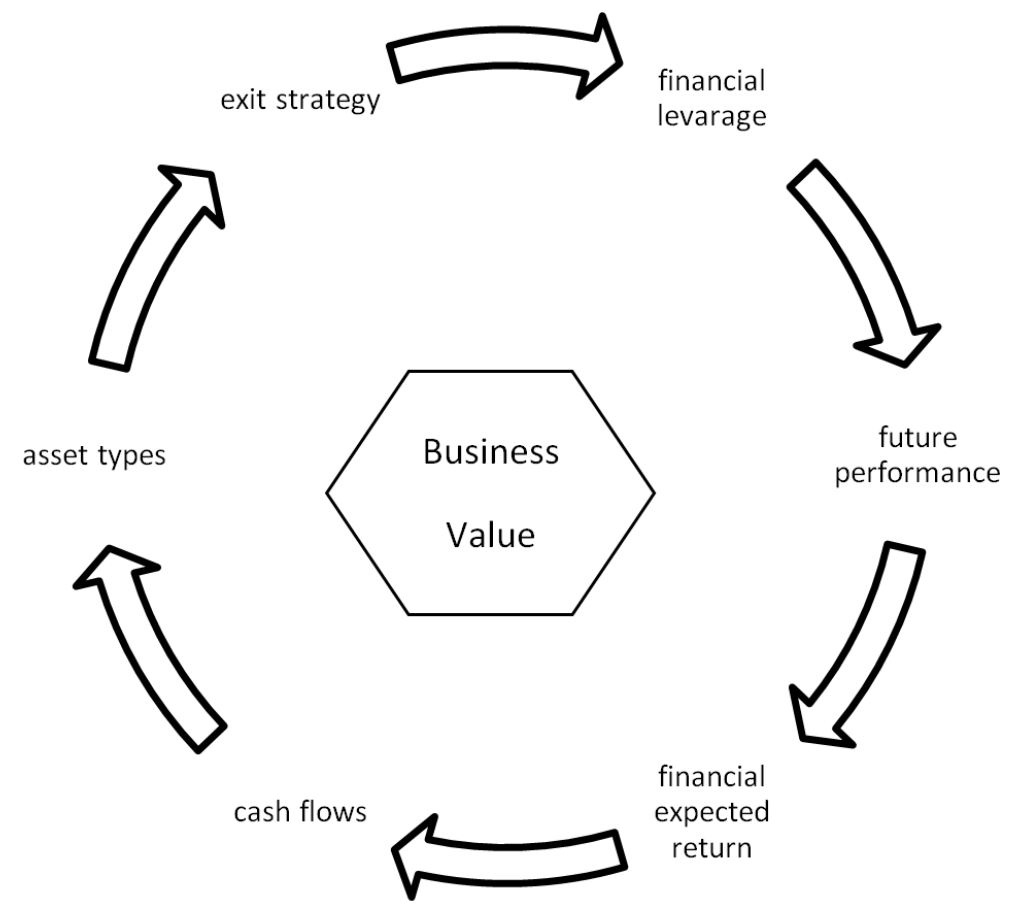

Figure 5. Business valuation drivers.

\subsubsection{Asset-Based Approach: A Going-concern and a Liquidation Asset Based Approach}

Asset based valuation approach is a type of business valuation in which the value of the company is determined by excluding the fair value of its assets from its total liabilities. in other words, asset based valuation is equal to Fair value of company's total assets minus its total liabilities in which case total assets include both tangible and intangible assets; the value of tangible assets is to be taken from company's balance sheet whereas intangible assets are calculated by using calculated intangible value (CIV) method or by simple estimate [30]. Such valuation approaches are not normally the primary methods used to value a company or business. However, these are often applied with conditions: for example, when the business is not a going concern, i.e. while it is not 
profitable or is found financially distressed or when it is believed that the highest and best use of the asset is to be realizing via liquidation. Besides, these methods may be applied for valuation of start up or early stage business that does not showing a trend of profit records. Further, these could be applied when the underlying assets are found responsible for the significant portion of the value of the business, such as property based business owning, for instance, offices, car homes, hotels etc. In this approach, the business is estimated as being worth the value of its net assets that could be determined by three common ways; book values (These amounts are unlikely to be relevant to any purchaser or seller), net realizable values (This amount would represent what should be left for shareholders if the assets were sold off and the liabilities settled) and replacement values (to determine what it would cost to set up the business if it were being started now) [29]. In sum, this approach utilizes book of accounts of the company for the book value of assets and often utilizes when the company is about to liquidate or no longer operational as going concern [30].

\subsubsection{Market Value Approach}

A market approach is a method of determining the appraisal value of an asset, based on the selling price of similar items. The market approach is a business valuation method that can be used to calculate the value of property or as part of the valuation process for a closely held business. Additionally, the market approach can be used to determine the value of a business ownership interest, security, or intangible asset. Regardless of which asset is being valued, the market approach studies recent sales of similar assets, making adjustments for differences in size, quantity or qualityii.

The market approach is a general way of determining the value of a business, business ownership interest, security, or intangible asset by using one or more methods that compare the subject to similar businesses, business ownership interests, securities, or intangible assets that have been sold (Mercer Capital, 2014) iii . According to this Business Valuation \& Financial Advisory Services (Mercer capital, 2014), there are three valuation methods under the market valuation approach: Transactions Method, guideline public company methods and guideline transactions Method.

The transactions method is a market approach that develops an indication of value based upon consideration of observed transactions in the ownership interests of the subject entity. Transactions should be scrutinized to determine if they have occurred at arm's length, with a reasonable degree of frequency, and within a reasonable period of time relative to the valuation date. Inferences about current value can sometimes be drawn, even if there is only a limited market for the ownership interests and relatively few transactions occur. Arguably, any transaction that has occurred in reasonable proximity to the valuation date should be disclosed and distilled even if it is not directly considered toward the valuation. Any transaction used to develop an indication of value for the entity, or more directly for the subject interest, is considered in the proper context (in terms of value definition) of other valuation methods developed in the appraisal.

The Guideline Public Company Method (GPCM) involves the use of valuation metrics from publicly traded companies that are deemed suitably comparable to the subject entity. Direct comparability is difficult to achieve in many situations, as most public companies are larger and more diverse than the subject, closely held entities in most business appraisals. However, the threshold for direct comparability need not be so inflexible that public companies with similar business characteristics are disqualified from providing guidance in the valuation of the subject company. In some cases, public companies may not be reliable for direct valuation purposes but may yield information helpful in ascertaining norms for capital structure assumptions and growth rate analysis. The selection of, adjustment of, and application of public company valuation data can be a complicated process involving significant appraiser skill and experience. Absent proper execution, the GPCM can render valuation indications that differ significantly from other methods and thus lead to confusing and/or flawed appraisal results.

The transactions method and the GPCM follow a generally recognized (more or less) set of procedures and practices. The guideline transaction method (GTM) is inherently different in its requirements due to potential idiosyncrasies in the underlying data.

\subsection{Business Valuation Process}

The first step in the process of business valuation is obtaining a full understanding of the broad over view of valuation requirements; business and business ownership interest, what is being valued. Industry analysis and market conditions are paramount important in this first step of business valuation process. In the second step, undertake both financial and qualitative analysis. By Qualitative analysis one can refer to analysis of securities via subjective judgment based on unquantifiable information, such as management expertise, industry cycles, strength of research and development, and labor relations, among others.

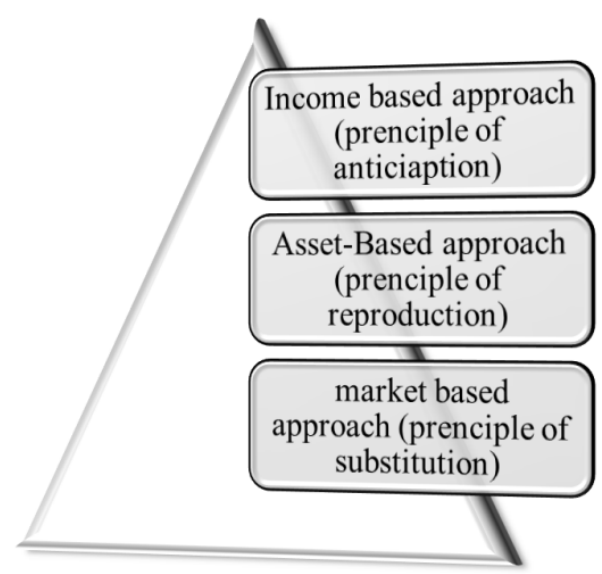

Figure 6. Business valuation approaches. 
The difference between qualitative and quantitative approach is similar to the distinction between human and artificial intelligence; while quantitative analysis uses direct imputes such as earnings multiples, profit margins, debt ratios, and the like, qualitative analysis, on the other hand, deals with intangible and inexact concerns which belongs to the social and experiential realm, such as brand, management trustworthiness, customer satisfaction, competitive advantage and cultural shifts which are difficult and arguably impossible to capture with numerical inputs, rather than the mathematical one. In the third step, the valuation methodology (income, market and asset based approaches) assessment is paramount important via taking in to consideration the nature of the business, the size of the business and the economic conditions so as to select a comprehensive approach for proper valuation of the business. In the forth step, quantitative adjustments and reconciliations should be performed in line with the established criteria, may be local generally accepted accounting principles (GAAP) or international financial reporting standards (IFRS) as issued by international accounting standards board (IASB) as adapted or adopted by a country. Finally, standardized report with full disclosure should be prepared and documented. In sum, the ten (10) qualitative factors affecting the value of a business have been justified Wall Street Mojo iv, as company's core business, quality management, customers and geographic exposure, competitive advantage, corporate governance, industry growth trend, competitive analysis, disruptive technologies, market share and regulations.

\section{Common Errors in Company Valuations}

The common errors in company valuation have been identified and documented by [31]. Around 119 common errors have been identified and comprehensively classified in to six categories; 1) Errors in the discount rate calculation and concerning the riskiness of the company; 2) Errors when calculating or forecasting the expected cash flows; 3) Errors in the calculation of the residual value; 4) Inconsistencies and conceptual errors; 5) Errors when interpreting the valuation; and 6) Organizational errors. The number of common errors has been updated by [31].

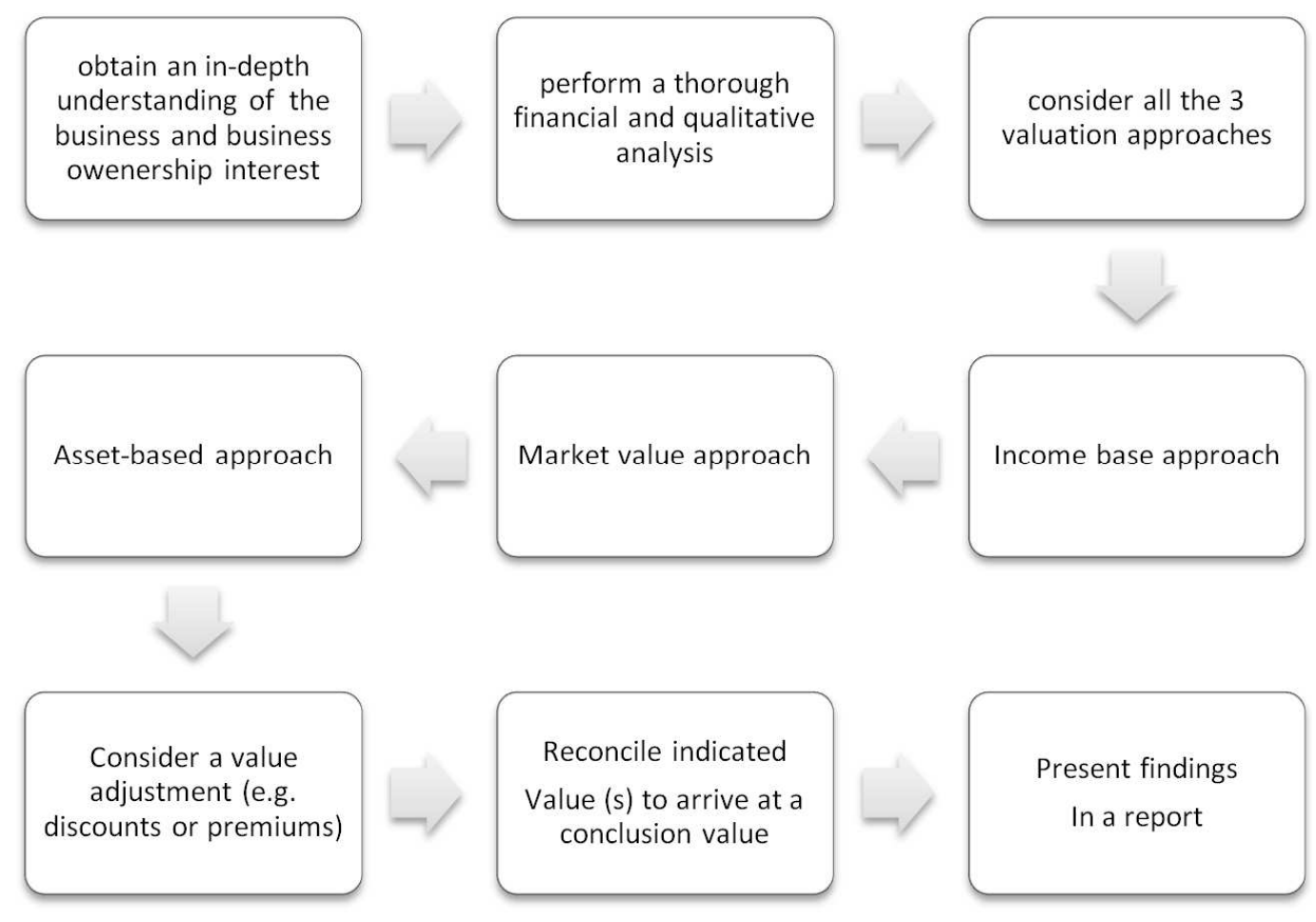

(Source: institute of professional accountants, South Africa)

Figure 7. The conceptual framework for Business valuation process.

\section{Conclusions}

Public companies in Ethiopia that are on the way to privatization such as Ethiopian airlines, Ethiopian telecom, railways, sugar factories, among others, should firstly be categorize in terms of such sufferings as debt burden (railway), capital problem (sugar factories) and inefficiency (telecom). Thus, apart from the political motives of the government, the privatization of such businesses should be towards alleviating such existing sufferings.

Regarding privatization strategies/modalities, Broad based or mass privatization, will be advisable for Ethiopian government than that of the conventional/traditional strategies (i.e. trade sale, Employee-Management buyouts, contracting-out and joint venture shares) due to the justification that such strategies involves privatization of large number of SOEs in equitable ways which led to the 
development of three broad based ownership strategies; voucher based programs, collective investment programs and public share offerings. These strategies are preferable due to the reason that they are politically popular, have better redistributive results, and can help capital market development, since Ethiopian government is on the way to institutionalize such a market in the country. Besides, this strategy can play an indispensable role on three major issues; political, wealth redistribution and institutional. Politically, it can make possible the spreading share ownership to the people at large or to specific subgroups such as the poor or an ethnic minority and some oligarchies, which are the current features of Ethiopians, and such a strategy will help the government not to concentrate the wealth of such SOEs in the hands of some oligarchies. On top of that, government can use this strategy to address the concern of wealthy distribution among the citizens, and at last the government can use this strategy in developing and deepening capital markets and related institutions as well.

It is obvious for many economies that SOEs can be both systemically and politically important. Many of these firms have been privatized in recent decades, for various political or economic reasons, which lead them to get a market-based valuation. In the process of valuing public enterprises to be privatized, having a market signal could be desirable for the reason that it could help in: informing the treasury of the net present value (NPV) of expected cash flows, enforcing some regulation on management, signaling market changes, and valuing discoveries and $R \& D$ that are slow to show up in cash flows (Wagner, 2017). In doing so, given the various business valuation methods discussed so far, it is fundamental for Ethiopia to institutionalize secondary market at least to mitigate the six common errors in the business/asset valuation process: as Errors in the discount rate calculation and analyzing the riskiness of the company; Errors when calculating or forecasting the expected cash flows; Errors in the calculation of the residual value; inconsistencies and conceptual errors; Errors when interpreting the valuation; and Organizational errors, inter alia. In sum, accordingly, for privatization to succeed in Ethiopia, it will be better for the government to excel its privatization process in this ways; liquidation, reprivatisation, decontrol and privatization, i.e., partial or full, and ahead of valuing enterprises it is better to institutionalize secondary market in the country.

\section{References}

[1] Deneke, S. (2001). private sector development in Ethiopia.

[2] Okecho. W. (n.d). Uganda's Privatization Strategy: A Diagnosis.

[3] Waigama, S. M. S. (2008). Privatization process and asset valuation A case study of Tanzania Doctoral Thesis in.

[4] De Castro, J., Uhlenbruck, K. (1997). Characteristics of Privatization: Evidence from Developed, Less-Developed and
Former Communist Countries. J Int Bus Stud 28, 123-143. doi: $10.1057 /$ palgrave.jibs.8490843.

[5] Bell, S. (1999). Privatization through Broad Based Ownership Strategies: a more popular option? Washington D.C: World Bank notes no. 33 .

[6] Tanyi, G. B. (1997). Designing Privatization strategies in Africa: Law, Economics \& Practice, And London: Prager Publishers.

[7] Nellis, J. (1999), Time to Rethink Privatization in Transition Economies?, Working Papers, World Bank - International Finance Corporation.

[8] United Nations (1993). Accounting, Valuation and Privatization, New York: United Nations Publications, ST/CT/157.

[9] Gray, C. W. (1996). In Search for Owners: Privatization \& Corporate Governance in Transition Economies. The World Bank Research Observe, 11 (2): 179-195.

[10] Welch D. (1998). The case-by-case approach to privatization: techniques and examples / Dick Welch, Olivier Fremond. p. cm.- (World Bank technical papers; no. 403) ISBN 0-82134196-0.

[11] Bulow, J. \& Klemperer, P. (1996). Auctions versus Negotiations. The American Economic review 86 (1): 180 194. Cambridge, MA; New York, and Melbourne: Cambridge University Press.

[12] Klein, M. (1998). Designing Auctions for ConcessionsGuessing the Right Value to Bid \& Winner's Curse, Washington DC: World Bank Note no. 160.

[13] Chole, E. (1993). Privatization and Deregulation in Ethiopian Industry: Journal of Ethiopian Studies, Vol. 26, No. 1, pp. 3358 .

[14] Fre'mond, O. \& Nellis, J. (1998). Pre-emptive Rights \& Privatization. Washington DC: World Bank Note no. 163.

[15] Murtha, T, P., and Lenway, S. A. (1994). Country capabilities and the strategic state: How national political institutions affect multinational Corporations' Strategies. Strategic $\begin{array}{llll}\text { management journal, } & \text { Vol, } & 15 & \text { (2). }\end{array}$ https://doi.org/10.1002/smj.4250151008

[16] Kikeri, S., \& Nellis, J. (2004). An assessment of privatization. World Bank Research Observer, 19 (1), 87-118. https://doi.org/10.1093/wbro/lkh014

[17] Megginson, William, Robert Nash, and Matthias van Brandenburg. (1994). the Financial and Operating Performance of Newly Privatized Firms: An International Empirical Analysis. Journal of Finance. 49: 403-452.

[18] Megginson, William and Jeffry Netter. (2001). From State to Market: A Survey of Empirical Studies on Privatization. Forthcoming, Journal of Economic Literature.

[19] Mugerwa, S. K. (2001). Globalisation, Growth and Income Inequality: The African Experience. OECD Development Centre Working Papers 186, OECD Publishing.

[20] Barberis, N., Shleifer, A., \& Vishny, R. (1997). A Model of Investor Sentiment, 49. https://doi.org/10.3386/w5926

[21] Nelson, L. D. (1994). An assessment of the Russian voucher privatization program author: Virginia Commonwealth University Irina Y. Kuzes, Znanie-sila, Moscow. 
[22] Estrin, S., \& Pelletier, A. (2016). Privatisation in developing countries: What are the lessons of experience? IZA Discussion Papers, 10297 (November), 15-22. Retrieved from http://hdl.handle.net/10419/149156

[23] Estrin, S., \& Pelletier, A. (2018). Privatization in developing countries: What are the lessons of recent experience? World Bank Research Observer, 33 (1), 65-102. https://doi.org/10.1093/wbro/lkx007

[24] Cummings, R. G., Martinez-vazquez, J., Mckee, M., \& Torgler, B. (2009). Journal of Economic Behavior \& Organization Tax morale affects tax compliance: Evidence from surveys and an artefactual field experiment, 70, 447457. https://doi.org/10.1016/j.jebo.2008.02.010

[25] Roland, R. (2008). Privatization: successes and failures. Columbia University Press, May 30, 2008 - Business \& Economics - 231 pages.

http://www.ethiomarket.com/bid/2006/jan06/jan_12 privatization_\& public ente rprise_supervision_authority.htm

ii https://www.investopedia.com/terms/m/market-approach.asp

iii https://mercercapital.com/assets/Mercer-Capital-ESOP-Trustee-Practice-AidMarket-Approach.pdf

iv https://www.wallstreetmojo.com/qualitative-factors-valuation/\#1
[26] Bunnell, P. (1997). Privatization in Sub-Saharan Africa: Progress and Prospects during the 1990s. World Development, Vol. 25, No. I 1, pp. 178\% 1803.

[27] Nellis, J. (2008). Privatization in Africa. What has happened? What is to be done? In Roland, G. (ed.), Privatization: successes and failures.

[28] Estrin, S. and Pelletier, A. (2015). Privatization in developing countries: What are the lessons of experience?

[29] Joseph, A., Yasseen, Y., \& Small, R. (2017). Business Valuation - Concept, (August).

[30] Kirk, W. C., \& Wishing, K. J. (2018). Fundamentals of the Asset-Based Business Valuation Approach, 3-14.

[31] Fernandez. P and Bilan. A. (2013). 110 Common Errors in Company Valuations. International Journal of Economics \& Business Administration pp. 33-78 Volumes I, Issue (1). 